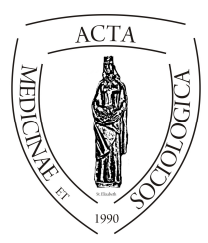

\title{
Romák mint kisebbségi jogi alanyok az Európai Unióban és Romániában.
}

\author{
Csipkés Hajnalka-Szende
}

PhD hallgató, Babeș-Bolyai Tudományegyetem Szociológia Doktori Iskola, 400604 Kolozsvár, 21 Decembrie 1989 sugárút, 128.

\section{INFO ABSTRACT}

\begin{tabular}{l}
\hline $\begin{array}{l}\text { Hajnalka-Szende Csipkés } \\
\text { szende_csipkes@yahoo.com }\end{array}$ \\
\hline Keywords \\
EU policies, \\
protection of minorities, \\
Roma integration, \\
strategies.
\end{tabular}

Hajnalka-Szende Csipkés
szende csipkes@yahoo.com

Roma minority as a legal entity in the $\mathbf{E U}$ and Romania. The present study aims to analyze the EU strategies against the discrimination over the Roma, as a population above nations, as well as the implementation of these strategies in the Romanian legal system. In order to complete the legal review, this study also includes among its objects the analysis of minority rights.

The European Union has no exclusive competences of minority rights. In fact, the minority rights issue falls within the sovereignty of Member States. However, the European Union may require indirectly that Member States respect the rights of minorities. It will be analyzed the actual regulations in Romania, which ensures special rights for minority ethnic groups.

The author is also mentioning national strategies dealing with the integration of the Roma and national offices which are ensuring legal aid.

Kulcsszavak
EU politikák,
kisebbségvédelem,
romaintegráció,
stratégiák

Absztrakt. Jelen tanulmány célja a romák, mint nemzetek feletti nép elleni hátrányos megkülönböztetések kiküszöböléséért folytatott Európai Uniós stratégiák elemzése, valamint ezek érvényesülése a román jogrendszerben. A roma ügy jogi áttekintése a kisebbségi jogok érintésével történik. Az Európai Unió nem rendelkezik kizárólagos hatáskörrel a kisebbségjogokat illetően, melyek jelenleg a tagállamok szuverenitásának részét képezik. Azonban az Európai Unió közvetett módon kötelezheti a tagállamokat a kisebbségi jogok tiszteletben tartására. Hangsúly tevődik Románia kisebbségvédelmi jogszabályaira, melyek az állam területén kisebbségben elő etnikumok különjogait biztosítják.

A szerző kitér a romák integrációjával foglalkozó nemzeti stratégiákra, valamint megemlíti a jogvédelem megvalósulását biztosító nemzeti hivatalokat is. 
Ez a tanulmány a XI. Nyíregyházi Doktorandusz Konferencián (2017. 12. 01., Nyíregyházi Egyetem) elhangzott előadás alapján készült.

\section{Bevezetés A nemzeti kisebbségek helyzete az Európai Unióban}

Az Európai Unió kisebbségvédelmi politikája hosszú ideig mellőzve volt (Szalayné, 2003). Ennek elsősorban az az oka, hogy az Európai Unió gazdasági céllal lett létrehozva, a későbbiekben pedig a tagállamok saját szuverenitásukat nem szerették volna tovább csökkenteni (Szajbély - Tóth, 2002). Azonban az elmúlt évek során a kezdeti passzív magatartás megváltozott. 1981-ben az Európai Parlament által elfogadott egyik határozat felszólította a tagállamokat, hogy támogassák a regionális nyelveket és kultúrákat. 1991-ben többek között az önállóvá vált kelet-európai államok elismerésének előfeltételévé tette a kisebbségek védelmét. Az Európai Unió ma már a teljes jogú tagságkérelmi feltételei közé sorolja az illető államban élő kisebbségek jogi és tényleges helyzetének védelmét, viszont nem ír elő egységes szabályozást. Az Európai Unió nem rendelkezik olyan jogalkotási hatáskörrel, amely felhatalmazná kisebbségvédelmi tárgyú jogszabályok kibocsátására, így az EU-tagállamokat nem kötelezheti a kisebbségi csoportok egyforma védelmére (Szalayné, 2003). 1992-ben a Maastrichti Szerződés elfogadásával az elsődleges joganyag részévé vált a kulturális és nyelvi sokszínűség védelme, viszont ,,annak ellenére, hogy az Unió rendelkezik hagyományokkal a kisebbségi nyelvek védelmét illetően, az uniós szabályozásban sem a kisebbség, sem a kisebbségvédelem kifejezésekkel - egészen a lisszaboni szerződés életbe lépéséig - nem találkozhattunk" (Felföldi, 2011). Ugyanakkor a Maastrichti Szerződés megteremtette a jogalapot a Regionális vagy kisebbségi nyelvek európai chartájának elfogadására (Felföldi, 2011).

A multikulturalitás a társadalmi integrációt nem az asszimilációval, „a másság megszüntetésével akarja megvalósítani, hanem a másság értékként való kezelésével. A nyelvi, etnikai, vallási vagy politikai kisebbségeket úgy nyeri meg, hogy segíti kulturális identitásuk megőrzésében" (Albert-Lőrincz - Albert-Lőrincz, 2012, 7). A multikulturalitás lényege a különböző típusú kisebbségi kulturális identitások erősítése (Albert-Lőrincz - Albert-Lőrincz, 2012).

Az Európai Unió Alapjogi Chartája, melyet 2000-ben írtak alá, meghatározó dokumentum a kisebbségi jogok szempontjából. A Charta egyesíti az EU alapvető jogait, azonban elfogadásakor még nem rendelkezett jogi kötőerővel. A 2009-es Lisszaboni Szerződés hatálybalépésével viszont a kezdeti helyzet megváltozott és az Alapjogi Charta jogi kényszerítő erővel lett felvértezve (Albert-Lőrincz, 2014). A Charta 21. cikkében a diszkrimináció tilalmát a nemzeti kisebbséghez való tartozáshoz is köti. A 22. cikk szerint az Unió tiszteletben tartja a kulturális, vallási és nyelvi sokféleséget.

Az Európai Unió Tanács 2000/43/EK irányelve a személyek közötti, faji- vagy etnikai származásra való tekintet nélküli egyenlő bánásmód elvének alkalmazásáról, más hátrányos megkülönböztetést tiltó dokumentumhoz hasonlóan szerepet játszik kisebbségjogi kérdésekben. Az irányelv személyi hatálya nemcsak az uniós állampolgárra, hanem harmadik államok polgáraira is vonatkozik (Szajbély - Tóth, 2002). 
A 2007-es Liszaboni Szerződés az Európai Unióról szóló szerződés és az Európai Közösséget létrehozó szerződés módosításáról az 1a. cikkében említést tesz a kisebbségi jogok tiszteletben tartásáról. Azonban az Európai Unió Müködéséről Szóló Szerződés nem sorolja fel a kisebbségi jogot az Unió hatáskörei között. Tehát amint már említésre került, a kisebbségi jogok kérdései kizárólag a tagállamok hatásköreibe tartoznak (Czika, 2011).

Az Európai Unió Múködéséről Szóló Szerződés 7. cikke szerint szankciók róhatók ki a 2. cikkben felsorolt értékeket megsértő tagállamokra. A szankciók nem korlátozódnak az uniós jog által megszabott területekre, vagyis annak ellenére, hogy a kisebbségi jogok a tagállamok exkluzív hatásköreihez tartoznak, ezek megszegése az Unió által büntetett (Czika, 2011).

Az Európai Unió a kisebbségek jogi védelmét három módon biztosítja: először is közvetlenül, az uniós jog alapján. Ehhez tartozik a harmadik országokban élő kisebbségek védelme, az emberi jogok alkalmazásával. Azonban a kisebbségvédelem nem képezi az unió kizárólagos hatáskörét, ezért nem szabhat ki a tagállamok számára kötelező erejü normákat; a második jogvédelmi eszköz közvetetten történik, nagyrészt a hátrányos megkülönböztetést tiltó, az egyenjogúságot biztosító normák segítségével; a harmadik eszköz pedig a tagjelölt államoknak előirt csatlakozási feltételekben nyilvánul meg. Ez a feltétel a csatlakozni kívánó ország területén élő nemzeti és etnikai kisebbségek jogainak tiszteletben tartására irányul (Szajbély - Tóth, 2002).

\section{Az Európai Unió romaintegrációs stratégiái}

Számos nemzetközi és európai uniós okmány a romákat, mint nemzetek feletti népként említik területi szétterjedésük alapján (Majtényi - Vizi, 2005). Habár az Európai Unió szerint a roma üggyel érdemben nemzetközi szinten lehet hatékonyan foglalkozni, léteznek uniós szinten kizárólag romákat érintő határozatok. Természetesen ezek mellett, a fent elemzett kisebbségeket érintő dokumentumok is hivatottak jogaik védelmezésére.

Az első roma érdekeltségü uniós szintü hivatalos dokumentumok 1995-re tevődnek, amikor az Európai Parlament (EP) határozatot fogadott el a romákkal szembeni megkülönböztetésröl. A határozat értelmében egy különleges jelentést rendel el haladéktalanul, és felszólítja a Bizottságot, hogy fokozza erőfeszítéseit a romák társadalomba való beilleszkedésének és a kultúrához való hozzájárulásának elősegítésére (Majtényi - Vizi, 2005).

A 2003-as Európai Parlament határozata a kisebbségi csoportokhoz tartozó nők helyzetéről az Európai Unióban, tekintettel a roma nők hátrányos helyzetére felhívja az érintett kormányokat, hogy tegyenek intézkedéseket a roma nők termékenységi és szexuális egészségének javítása érdekében, akadályozzák meg és vessenek véget a kényszerített sterilizációnak, és mozdítsák elő a családtervezést, a korai házasságok alternatíváit és a szexuális oktatást (Majtényi -Vizi, 2005).

Egy másik fontos Európai Parlament által elfogadott határozatra 2005-ben került sor, mely A romákról az Európai Unióban címet viseli, mely a a romák gazdasági, társadalmi és politikai integrációjának javítására hívja fel a figyelmet (Majtényi Vizi, 2005). 


\section{Románia nemzeti kisebbségeinek jogi helyzete}

Románia, mint az Európai Unió tagállama, az Emberi Jogok Egyetemes Nyilatkozatának és más nemzetközi szerződések részeseként, valamint az egyenlő bánásmód, jogegyenlöség, valamint minden hátrányos megkülönböztetés alapértékek jegyében, köteles a nemzeti vagy etnikai kisebbségi jogok támogatásara.

Románia Alkotmánya a 6. cikkében az identitáshoz való jogcímmel megfogalmazza a nemzeti kisebbségi csoporthoz tartozó egyének védelmét: „(1) Az állam elismeri és biztosítja a nemzeti kisebbségekhez tartozó személyek jogát az etnikai, kulturális, nyelvi és vallási identitásuk megőrzéséhez, fejlesztéséhez és kifejezéséhez. (2) A nemzeti kisebbségekhez tartozó személyek identitásának megtartását, fejlesztését és kifejezését célzó állami védőintézkedéseknek meg kell felelniük a többi román állampolgárhoz viszonyítva az egyenlőség és a diszkrimináció tilalma elveinek." Ehhez kapcsolódik a 48/2002. számú a diszkrimináció megelözéséröl és büntetéséröl szóló törvény, melyet a 2003. évi 77. számú kormányrendelet, a 2004. évi 27. számú törvény, és a 2006. évi 324. számú törvény módosította ill. kiegészítette, majd 2007-ben tették újra közzé.

Albert-Lőrincz szerint $(2017,18)$,az egyenlőség és egyenlőtlenség elve alatt az emberi faj diszkrimináció mentességét jelenti, nem pedig a különbözőség nélküliségre vagy a különbségek meglétére utaló fogalmak. Az emberek egyenlő méltósággal születnek, ezért a társadalmaknak arra kell törekedniük, hogy minden ember számára biztosítsa az esélyek egyenlöségét."

Az Alkotmány mellett jelenleg Romániában számos olyan hatályos törvény létezik, mely „nemcsak a kisebbségi létet teszik elviselhetőbbé, hanem a fennmaradás feltételét is jelenthetik" (Fábián, 2002, 1).

A 215/2001. számú helyi közigazgatásról szóló törvény az egyik legmeghatározóbb törvény a kisebbségi szempontból, melynek szakaszai túlnyomórészt a kisebbségek kollektív jogait biztosító rendelkezéseket tartalmaznak. A fent említett törvény 19. szakasza értelmében azokban a területi-közigazgatási egységekben, amelyekben a lakosság több mint 20 százaléka valamely nemzeti kisebbségekhez tartozik, a helyi közigazgatási hatóságoknak, alárendelt közintézményeiknek, valamint a dekoncentrált közszolgálatoknak biztosítaniuk kell az anyanyelv használatát is a velük fenntartott kapcsolatokban, az Alkotmány, a jelen törvény és a Románia által részes félként aláírt nemzetközi szerződések elörásainak megfelelően. Szintén a helyi közigazgatási törvény kimondja, hogy azokban a területi-közigazgatási egységekben, amelyekben a lakosság több mint 20 százaléka valamely nemzeti kisebbséghez tartozik, a szabályozó jellegü határozatokat a kisebbség anyanyelvén is köztudomásra kell hozni. A kisebbséghez tartozó személyeknek jogában áll, hogy anyanyelven nyújtsanak be szóbeli vagy írásos kérést a helyi és megyei közigazgatási szervekhez, valamint, hogy ugyanazon a nyelven kapjanak választ (76. szakasz).

Amennyiben a lakosság több mint 20 százaléka valamely nemzeti kisebbségekhez tartozik, ezen feltétel számos helyen megjelenik (Fábián, 2002), mely a kisebbségi kollektív jogok gyakorlatára jogosítja a kisebbségi közösséget. Ilyen például a helységnevek kifüggesztése anyanyelven, a hivatalos nyelvü mellett, az intézmények ne- 
vének a kisebbség nyelvén történő kifüggesztése, az anyanyelven történő házasságkötés, olyan személyek alkalmazása helyi közigazgatási szerveknél, akik értik és beszélik az illetö kisebbség nyelvét (Fábián, 2002).

Az Alkotmány 32. szakasza értelmében ,garantált a nemzeti kisebbségekhez tartozó személyek joga anyanyelvük tanulásához és a jog ahhoz, hogy ezen a nyelven oktathassák őket”. A jelenleg is hatályos 1/2011. számú oktatási törvény szabályozza a nemzeti kisebbségekhez tartozó egyének anyanyelven történő oktatáshoz való jogát. Ezt az 85/1994. számú törvény előzte meg. A hatályos oktatási törvény 45. szakasza szerint ,,a nemzeti kisebbségekhez tartozó személyeknek joguk van anyanyelvükön tanulni és müvelödni az oktatás minden szintjén és formájában, valamint azokban az oktatási típusokban, amelyekre elégséges igény létezik, a törvény előírásainak megfelelően. A helyi igények függvényében, kérésre és a törvényes elöirásoknak megfelelően a nemzeti kisebbségek nyelvén oktató csoportok, osztályok, szakok vagy iskolák szervezhetők.

A büntetőjogban is számos kisebbségvédelmi elem található, mivel ,a büntetőjog fontos szerepet játszik a diszkrimináció megelőzésében és büntetésében, tekintetbe véve egyrészt a tényt, hogy szabályozza a társadalmilag fokozottan veszélyes diszkriminatív cselekedeteket, másrészt azt, hogy a legsúlyosabb és leginkább elbátortalanító hatású büntetéseket szabja meg, ideértve a szabadságtól való megfosztást is" (Chiriță - Săndescu, 2008, 85).

A 2014-töl hatályos új büntetőtörvénykönyv 77. szakaszában a következőket minősíti súlyosbító körülménynek: büncselekmény elkövetése faj, nemzetiség, etnikum, nyelv, vallás, nem, szexuális beállítottság, nézet, politikai hovatartozás, meggyőződések, vagyon, társadalmi származás, kor, fogyatékosság, nem fertőző krónikus betegség vagy HIV/AIDS megbetegedés alapján.

A 297. cikkely pedig annak a közhivatalnoknak a cselekedetét bünteti, aki megsérti egy személy törvényes érdekeit, valamint a diszkriminatív indítékokat. A 369. szakasz büncselekménynek ítéli azon cselekedetet, mely gyülöletkeltés vagy a megkülönböztetés felbujtására törekszik bármilyen eszköz segítségével. A törvénykönyv a fajirtási tettekre életfogytig tartó letöltendő börtönbüntetést szab ki (438. szakasz). A bünvádi eljárási törvénykönyv 329. szakasza szerint a nemzeti kisebbséghez tartozó román állampolgárisággal rendelkező vádlott kérheti a vádirat anyanyelven való közlését is.

A 2013-tól hatályos polgári perrendtartási törvénykönyv is tartalmaz kisebbségi jogi garanciákat. A törvénykönyv 18. szakaszának értelmében polgári eljárás román nyelven folyik. A nemzeti kisebbségekhez tartozó román állampolgároknak viszont jogukban áll anyanyelvükön kifejezni magukat a bíróság előtt. Az államnak biztosítania kell a kisebbséghez tartozó egyén jogát attól függetlenül, hogy beszéli-e az ország nyelvét vagy sem.

Tehát abban az esetben is, ha egy nemzeti kisebbséghez tartozó személy tökéletesen beszéli a hivatalos nyelvet, de személyes okok miatt nem kíván megszólalni ezen a nyelven, az állam köteles megteremteni azokat a körülményeket, ez alatt értendő például tolmács biztosítása, hogy az illető e jogával tudjon élni.

Ehhez hasonló rendelkezéseket tartalmaz a büntetőjogi eljárási törvénykönyv 12. cikkelye. 


\section{Romániában élő romák helyzete}

Az ezredfordulós évek brüsszeli jelentései szerint a romákat érintő elöítéletek nagyon elterjedtek Romániában. Habár hivatalosan a törvény tiltja a hátrányos megkülönböztetést, ennek ellenére a gyakorlatban a foglalkoztatás és oktatás terén a törvénytelen hátrányos megkülönböztetésre számtalan példa akad. Továbbá a jelentés megjegyzi, hogy az elmúlt évek előrelépésekkel is jártak, ilyen például a Nemzeti Kisebbségek Tárcaközi Bizottságának létrejötte, mely támogatja a romák részvételét az őket érintő ügyek döntéshozatali eljárásában. A roma közösség által létrehozott Roma Egyesületek Munkacsoportja a közhatóságokkal való kapcsolattartás céljából müködik. A jelentést követő értékelés alapján a Bizottság, úgy értékelte, hogy a román állam teljesíti a koppenhágai kritériumokat, azonban a romák helyzete továbbra is fokozott figyelmet igényel (Majtényi - Vizi, 2005).

A roma integráció folyamata viszont néhol regresszív tendenciákat mutat, a kormánystratégiák alkalmazása elhúzódott, a romákért felelős bizottság munkásága érdemben nem változtatott a romák helyzetén, illetve a Romaügyi Nemzeti Hivatal szükös anyagi keretek között müködött annak ellenére, hogy prioritásként volt számon tartva. A 2000-es év pozitívumai közé tartozik az Oktatásügyi Minisztérium azon kezdeményezése, hogy segítse a romák oktatáshoz való hozzáférését fenntartott helyek biztosításával. Az ezt követő évben elfogadták a romák körülményeit javítandó nemzeti stratégiát. "A stratégia 10 évre szól. A dokumentum megfogalmazza azt a gondolatot, hogy a romák hátrányos megkülönböztetése komoly probléma Romániában. A stratégia céljai között szerepel elöítéletének megváltoztatása, a romák életkörülményeinek javítása és a romák civil társadalomban történő szerepvállalásának ösztönzése. A fentiek megvalósítása érdekében minden megyében helyi roma hivatalokat állítanak fel, romáknak szeretnének hivatali munkát biztosítani (Majtényi -Vizi, 2005). A roma stratégia megvalósításának egyik gyenge pontja, hogy az anyagi támogatás nem vált hozzáférhetővé. A stratégia a lakásellátással mindezidáig nem foglalkozott kellő mértékben, pedig ez az egyik legnagyobb, a roma közösséget érintő probléma (Majtényi -Vizi, 2005).

A 2003-as jelentések szerint a Nemzeti Diszkriminációellenes Tanácshoz beérkezett panaszok több mint a fele a romáktól érkezett. A 2004-es és 2005-ös jelentések is a Roma Stratégia kivitelezésének eredményeire fektet hangsúlyt. Megjegyzendő, hogy a stratégia hatására az oktatás területén körvonalazódnak elörelépések, azonban a roma elleni diszkrimináció még mindig a román társadalomra jellemző magatartás (Majtényi - Vizi, 2005).

2006-ban a Stratégiát az 522. számú kormányhatározattal módosították. Egy új cselekvési tervet alakítottak ki a 2006-2008-as időszakra. A cselekvési irányok újrarendeződtek és összevonódtak. A módosított Stratégia meghatározza az új Országos Roma Ügynökség szerepét is, amelyik felelős a Stratégia alkalmazásáért (Moisă, 2008). A 2008 utáni periódusra nem fogadtak el újabb stratégia módosításokat. Azonban 2012ben újabb változtatások történtek, melyek 2012-2014-es periódusra fokuszáltak. 
A jelenlegi hatályos stratégia a 2015-2020-as évekre vonatkozik. Az előző stratégiákhoz hasonlóan a romák helyzetének javulása a prioritás az oktatás, kultúra, egészségügy területén. Az illetékes román intézmények, valamint a civil szervezetek és az Európai Unió szervezetei közötti párbeszéd könnyítésével szeretnének célt érni.

\section{Következtetések}

A romák helyzete európai és hazai szinten speciális figyelmet és intézkedést élvez, valamint igényel, viszont a kirekesztettség szociális problémája továbbra is fennáll. Uniós és nemzeti szinten az alapvető emberi jogok, illetve a kisebbségi különjogok mellett számos törekvés és program létezik a romák kirekesztettségének megszüntetése céljából, azonban ezek nem elegendőek sem a társadalmi elöítéletek teljes mértékü megváltoztatásához, sem a romák életkörülményeinek javításához. A romák kirekesztettségének megszüntetéséhez nagymértékben hozzájárulhatnak azon társadalomtudományi, humán kutatási projektek eredményei, amelyek az Európában élő cigány népességre, annak különböző csoportjaira, közösségeire irányulnak, amelyek további adalékokat szolgáltatnak a stratégiai kezdeményezések gyakorlatban való megvalósításához (Juhász - Garai, 2007).

\section{Irodalomjegyzék}

1. Albert-Lőrincz, Cs. (2014): Diminishing national sovereignty affecting EU member states' citizenship? Globalization and Intercultural Dialogue. Multidisciplinary Perspectives. ARHIPELAG XXI PRESS.

2. Albert-Lőrincz, Cs. (2017): Szociálpolitikai alapok és a jóléti perspektívák térvesztése, Kolozsvári Egyetemi Kiadó.

3. Albert-Lőrincz M., Albert-Lőrincz Cs. (2012): A multikulturalizmus, Magiszter, X. évfolyam, 3 sz. 5-20.

4. Chiriță, R., Săndescu, A. (2008): A nemzeti kisebbségek jogaira vonatkozó román jogszabályok elemzése.

http://www.jakabffy.ro/magyarkisebbseg/pdf/004chirita.pdf, (letöltés időpontja 2017 november 14$)$.

5. Czika, T. (2011): A kisebbségi jogok kérdése az EU-jogban Lisszabon után, http://jog.sapientia.ro/data/tudomanyos/Periodikak/scientia-iuris/2011-3/hu7Czika.pdf, (letöltés időpontja 2017. november 14.)

6. Fábián, Gy. (2002): Az identitáshoz való jog Romániában, a lakosságnyilvántartás tükrében. Kisebbségkutató Intézet. 4. sz. 18.

7. Felföldi, R. (2011): A kisebbségi nyelvek helyzetének változása az Európai Unióban. https://btk.ppke.hu/uploads/articles/6414/file/felfoldirita.pdf, (letöltés idöpontja 2017. november 14.)

8. Juhász, G., Garai P. (2007): Human Research in the Non-Profit Sector. The role and importance of human resources and organizational development in fostering operational effectiveness of the organizations in order to facilitate social and 
labour market integration. Pécs: Universitiy of Pécs, Palatia Press, Győr, 207 p. ISBN 978-963-642-174-8.

9. Majtényi, B., Vizi B. (2005): Európa kisebbsége. A roma kisebbségek nemzetközi dokumentumai. Gondolat Kiadó, Budapest.

10. Moisă, F. (2008): Közpolitikák a roma-problémák kezelésére. Nemzetpolitikai Szemle.

11. Szalayné Sándor, E.(2003): A kisebbségvédelem nemzetközi jogi intézményrendszere a 20. században. Gondolat Kiadó Kör, Budapest.

12. Szajbély, K., Tóth, J (2002): Kisebbségvédelem az Európai Unióban.

http://www.hhrf.org/kisebbsegkutatas/kk_2002_02/cikk.php?id=1134, (letöltés időpontja 2017. november 14.)

Jogszabályok

1. Az Európai Unió Alapjogi Chartája: (2000).

2. Az Európai Unió müködéséről szóló szerződés: (2007).

3. Lisszaboni Szerződés az Európai Unióról szóló szerződés és az Európai Közösséget létrehozó szerződés módosításáról: (2007).

4. Európai Unió Tanács 2000/43/EK irányelve a személyek közötti, faji- vagy etnikai származásra való tekintet nélküli egyenlő bánásmód elvének alkalmazásáról.

5. Románia Alkotmánya: (2003).

6. 215/2001. számú törvény a helyi közigazgatásról: (2001).

7. 286/2009. számú törvény, az Új Büntetőtörvénykönyv: (2014).

8. 134/2010. számú törvény az új polgári perrendtartásról: (2013).

9. 134/2010. számú törvény az új büntetőjogi perrendtartásról: (2014).

10. A Kormány stratégiája 2015-2020 évekre a román állampolgársággal rendelkező roma kisebbségek beilleszkedéséről. 